\title{
The Roles of the Institution of Pesantren in the Development of Rural Society: A Study in Kabupaten Tasikmalaya, West Java, Indonesia
}

\author{
Mohamad Mustari ${ }^{1}$ \\ ${ }^{1}$ Faculty of Education, University of Malaya, Kuala Lumpur \\ E-Mail:moh_mustari@yahoo.com
}

\begin{abstract}
Pesantrens are the oldest non-formal and traditional Islamic educational institution in Indonesia. These boarding institutions are uniquely Indonesian phenomenon, not found in other parts of the world. Nowadays, there is a widespread misjudgment that the pesantrens are said to train terrorist groups, promote Islamic fanaticism, and propagate conservative culture. Hence, some of the pesantrens are changing their paradigm, that is, from conservatism to modern-progressivism, while some others prefer to remain the same. The purpose of this study was to make an in-depth systematic analysis of the roles and contributions of pesantrens in the development of rural villages in Java, particularly in Tasikmalaya district which by itself had 761 pesantrens. This study employed the multiple case-study method. The cases were three large pesantrens and three small pesantrens, all located in Kabupaten Tasikmalaya. The pesantrens were in three categories: traditional, modern, and combination. Interview, observation, and document analysis were used to collect data. Face-to-face interviews were based on a standard check list developed for the study. The findings showed that pesantrens developed and implemented their own development plans, both for their own development and for rural development, as most pesantrens located in the rural areas.
\end{abstract}

Keywords: Pesantren, development, rural society

\section{A. INTRODUCTION}

Indonesia is populated by various ethnicities, cultures, languages, and religions. But the majority of the inhabitants, around 85 percent, embraces Islam (BPS, 2004). Islam had spread in Indonesia in the 12th century; and at the same time, there were mushroomed non-formal Islamic education in Indonesian society in such institutions as mosques and pesantrens. The position of the religion and Islamic institutions in Indonesia had spread widely and strongly through educational institutions such as pesantren covering until all of 33 provinces. This institution of pesantren has now 16,015 by its various kinds in throughout districts in di Indonesia (Departemen Agama, 2006).

Generally, this institution of pesantren has a philosophy that education is an effort to form a perfect human being, and not only to develop human capital or to build up an ordinary human resource. A perfect human being is being a comprehensive human covering those aspects as spiritual, intellectual, vocational, social, physical, cultural, and emotional, and this can be trained by such institutions as mosques and pesantrens. By this, there is ideological conflict of education in Indonesia: based on Islamic philosophy on the one hand and based on Western capitalist utilitarian philosophy on the other having influenced by Dutch colonial administration in the 16th century (Abdullah, 1986). 
Etymologically, "pesantren" and the original word "santr" comes from Tamil meaning "religious teacher". Another source says that the word is coming from Indian "shastr" from the original "shastra" meaning "sacred books", "religious books", or "books on knowledge". Outside Java island, this educatonal institution is called by other names such as surau (in West Sumatra), dayah (in Aceh), and pondok (in other areas) (Ensiklopedi Islam, j. IV, 1994). In the usage of Indonesian today two terms of "pondok" (Arabic: barrack or hotel) and "pesantren" mostly can be interchangable, even can be merge into "pondok pesantren" which usually can be shortened into "ponpes" (Mansurnoor, 1990).

According to Dhofier (1983), the word "pesantren" comes from the word "santri" itself, being added by prefix "pe" and sufix "an", meaning public house for the santri (students). In short, pesantren is a public house or a place for the students of religious learnings (Kamus Besar Bahasa Indonesia, 1995).

Based on the data by the Ministry of Religious Affairs year 2005/2006, there are pesantrens in every province of the Republic of Indonesia. The amount of the pesantrens are 16,015 with $3,190,394$ santri (students) and 276,223 ustaz (religious teachers) and 44,450 kiyais (religious leaders). The amounts of pesantrens in every province are varied between 12 until 3684 pesantrens (Depag, 2006).

Kabupaten Tasikmalaya which has 39 sub-districts (kecamatan) and 351 villages (desa/kelurahan) has more than one pesantren in almost every village. Hence, Kabupaten Tasikmalaya sufficiently can be called as "kota santri" (santri town). Among big pesantrens in Kabupaten Tasikmalaya, that is the biggest and populated by more than 500 santris, are: Pesantren Cipasung in Singaparna; Pesantren Miftahul Huda in Manonjaya; and Pesantren Suryalaya in Ciawi.

\section{B. METHODOLOGY}

This research takes account of social development which is a program of prosperity or aid for the poor through the fulfillment of their necessities, covering not only opportunities to get a job, but also accesses to public services, such as education, health, housing, transportation, water, etc. (Korten and Alfonso, 1981). Hence, the conception of development here is the conception of "integrative development".

Here, then, besides using indicators of development made by the government, especially by the Board for Central Statistics (Badan Pusat Statistik/BPS), this study also used public opinion survey to gain the data on the impact of the pesantrens to the development of the villages.

To gather the data, this research conducted some methods as follow:

1. For comprehensive study to the pesantrens being researched, this study used in-depth interview and observation.

2. For getting information on environmental data, especially the physical one, this study used secondary data, especially from such governmental institutions as district, provincial, and central government.

Therefore, this study used two categories of instruments: interview and observation. This directly made sure of the reliability of data and the findings by way of triangulation. 
Population is defined as a group of potentials the result of which will be generalized (Salkind, 2000) or all groups which will be studied (Chua, 2006).

Population of this research is the pesantrens in Kabupaten (District) Tasikmalaya, West Java, around 761 pesantrens. The samples of this population are pesantrens regarded as representatives of the title of this research. In this context, pesantrens in Kabupaten Tasikmalaya are divided into three categories: Modern (khalafi), Traditional (salafi), and Combination (the combination between the Modern and Traditional). Quantitatively, pesantrens can also be divided into two kinds: Big pesantrens (have more than 300 santris) and Small pesantrens (have less than 300 santris). From about 761 pesantrens in Kabupaten Tasikmalaya, six pesantrens are picked up to represent the above categories, those are:

1. Pesantren Miftahul Huda, Manonjaya representing Big Traditional pesantrens.

2. Pesantren Asy-Syahidiyah, Cisayong representing Small Traditional pesantrens.

3. Pesantren Al-Furqon, Singaparna representing Big Modern pesantrens.

4. Pesantren Persis, Rajapolah representing Small Modern pesantrens.

5. Pesantren Suryalaya, Pagerageung representing Big Combination pesantrens..

6. Pesantren Ar-Riyadh, Leuwisari representing Small Combination pesantrens.

The choice of pesantrens is done purposively, i.e. the choice based on information-rich cases (Patton, 2002). Quantitatively, the above six pesantrens cannot be properly appropriate to represent 761 pesantrens existed and listed in Kabupaten Tasikmalaya. But because of most pesantrens in Tasikmalaya are categoriezed as the same conditions and characteristics, such case taking should not necessarily based on the formula of $20 \%$ of the population. The choice of cases is rationalized to get representative variation.

Besides, a list of question is also used to get a general picture of the conditions of pesantren and to fulfill the triangulation of the data. The respondents for this list of question are divided into three main groups:

1. Pesantren insiders: kiyai, santri and ustaz.

2. General society including formal leaders (head of the village and head of the sub-districts), informal leaders (public figures) and ordinary people (farmers, workers, retailers, employees, etc.).

3. Pesantren-related society: pesantren alumni and santri's parents.

The sum of respondents can be seen in the following table:

Table 1. Respondents of the List of Questions

\begin{tabular}{|c|c|c|c|}
\hline Group & Kinds of Respondents & \multicolumn{2}{|c|}{ Amount } \\
\hline & & Respondents & Group \\
\hline \multirow{2}{*}{ Pesantren Insiders } & Kiyai & 4 & 18 \\
& Ustaz & 4 & 10 \\
\hline \multirow{2}{*}{ General Society } & Santri & 4 & 9 \\
& Formal Leader & 2 & 15 \\
\hline \multirow{2}{*}{ Pesantren-related Society } & Informal Leader & 3 & 40 \\
\hline \multicolumn{2}{|r|}{ Amount of respondents every sub-district } & 5 & 42 \\
\hline \multicolumn{2}{|r|}{ Total amount of respondents (6 sub-districts) } & 252 & \\
\hline
\end{tabular}

Respondent's taking based on the method of "quota", that is, the choice of the subjects is based on the categories existed in the population (Chua, 2006) based on the signs given by the formal and informal leaders of the society. 


\section{Problems of Study}

Theoretically, the main problem of this study is to see how far the validity and application of the theory of dualism and modernization theory, theory of social change, and leadership theory of development by the kiyais in the contexts of roles and functions of pesantrens in the development of rural societies in Indonesia. Until this time previous studies on pesantrens are not being able to give theoretical description on the rationale of the development of pesantrens, its activities and roles in the development of rural societies.

By focusing more attention to the cases of pesantrens in Kabupaten Tasikmalaya, the problems of study can be formulated in such question of research as the following: "Syntethically, what is the variety of roles and participation of the pesantren from the facets of economic, social, religious, cultural, and vocational training in the development of rural societies?"

\section{Objectives of Study}

This study has the following main objectives:

1. To investigate the conditions of the management of the pesantrens in Kabupaten Tasikmalaya.

2. To get social views on the relevance and image of the pesantrens.

3. To describe analytically the roles and potentials of the pesantrens and their environments, in relation to the possibility of the roles of pesantrens as an institution or agent of social change in rural areas, which can be able to be independent as well as to be participated in the development of the villages.

\section{Findings from the Pesantrens in Tasikmalaya}

\section{a. General Description of the Pesantrens in Tasikmalaya}

Tasikmalaya, as the location of this research, is one of the 25 kabupaten/town within the administration of West Java Province, Indonesia. This district is located more or less $90 \mathrm{~km}$ from the province capital (Bandung) to the southeast, or around $380 \mathrm{~km}$ southeast of Jakarta. To the north this region faces Kabupaten Ciamis and Kota Tasikmalaya, to the south there is Indian Ocean, to the west there is Kabupaten Garut, and to the east there is Kabupaten Ciamis. The capital of Kabupaten Tasikmalaya is Singaparna. This district of 2,712,52 km2 is a mountainous area with its peak at Mount Galunggung and Mount Talagabodas (Atlas Provinsi, 2006).

The population of Kabupaten Tasikmalaya in 2007 is 1,686,633 souls with its density of 615 souls/km2 (Kabupaten Tasikmalaya Dalam Angka, 2008). For making their living most of the population worked on farming sectors and husbandry; the others worked in such other sectors as merchandise, services, public service, non-government business, etc. The unique thing of Tasikmalaya is the fact that there are so many cottage industries producing clothes, embroidery, wood sandals (kelom), and handy craft (Pikiran Rakyat, 15 April 2009).

Based on the demographical data of 2007, the religious adherents of Kabupaten Tasikmalaya are 99.97\% Muslims $(1,686,098)$; the others are Christians, 149 souls $(0.001 \%)$, Catholics 246 souls $(0.014 \%)$, Hindus 91 souls $(0.005 \%)$, Buddhists 8 souls $(0.0005 \%)$, and others 41 souls $(0.002 \%)$. Based on this data, Tasikmalayan people are religious people. This is helped by the fact that there are so many religious (Islamic) educational institution, i.e. pesantren. 
If we make a classification, those pesantrens are rightly different in their stories. Some pesantrens come from the charisma of kiyai such as Pesantren Miftahul Huda, Asy-Syahidiyah, Ar-Riyadh, and Suryalaya. Some others come from socio-religious organizations such as Pesantren AlFurqon of Muhammadiyah and Pesantren Persis.

Mostly, however, those pesantrens are founded first before formal schools of the government. Such is because pesantren is a manifestation of effort of socialization of education to the young generation by previous generation accentuating religious studies and Islamic culture. And such effort is not limited into the facilities. Hence, activities of Islamic learning had been done before the pesantren being established. Having a pesantren been established, then schools or madrasahs were also founded within the pesantren.

Nevertheless, there are some pesantrens founding system of school within the pesantren at the very beginning. Hence, pesantren and school are slightly identical. This happens in such modern pesantrens as Al-Furqon, Singaparna. The difference is that in a school the students come back to their homes, while in a pesantren the santris do not come back to their homes but live in the pesantren and continue the programs of the pesantren.

There is another thing in this tradition of pesantren, i.e. the tradition of following the maternal pesantren. Here the first pesantren is a model for the next pesantren. It means that when a santri felt that he is able to establish a pesantren, he will found it in another area, such as in his home town by taking the pesantren he learnt in as the model. This, for example, was done by alumni of the Pesantren Miftahul Huda. Unsurprisingly, then, if Pesantren Miftahul Huda admitted that there are around 1000 pesantrens produced out of it. According to one of its ustaz, the characteristics of pesantren modeling to the Miftahul Huda is that there always be some name of 'Miftah' in the beginning of the next pesantren, such as 'Miftahul Ulum', 'Miftahul Jannah', etc. Or there is some label of 'Huda' in the last name of the next pesantren, such as 'Manbaul Huda', 'Thoriqul Huda', etc. Or even there are some pesantrens taking the name of the original name of 'Miftahul Huda' themselves.

Such thing as 'follow the leader' is admitted by other pesantrens. Pesantren Ar-Riyadh, for example, admitted that there are 70 pesantrens established by its alumni. Pesantren AsySyahidiyah also acknowledged that there are some 40 pesantrens founded by its alumni.

Yet, not all pesantrens had the same way in the pesantren 'breeding'. Pesantren Suryalaya, for instance, had no alumni made pesantren. Such is because the focus of education of Suryalaya is not to produce religious leaders (ulama) mastering religious studies and being pesantren managers. The focus of Suryalaya is to spread its religious doctrines, i.e. Tariqat Naqsabandiyah Qodiriyah (TNQ) with its product of therapy such as for curing drugs' addicts, named 'Inabah.' Hence, something which can be traced is in the facet of Suryalaya's propagation, that is, the establishments of tariqat adherent groups (Talqin) and Inabah in many areas in Indonesia, even until outside the country such as in Singapore, Malaysia, Brunei, even Australia.

The tradition of 'follow the leader' did also not happen in such modern pesantrens as Al-Furqon and Persis. Such is because here the loyalty of the santri is not to certain pesantren, but to the doctrines embraced by the organizations. The model, here, is not the pesantren, or kiyai, but the organization itself. For instance, even though there is a tradition of 'follow the leader', but owing to the spirit of egalitarianism of the Persis's members, 'follow the leader' to the pesantren is not a matter of course. This also happened to the Muhammadiyah's members. 
Table 2. Comparison of the Samples of Pesantrens in Kabupaten Tasikmalaya.

\begin{tabular}{|c|c|c|c|c|c|c|}
\hline \multirow{2}{*}{ Subject } & \multicolumn{2}{|c|}{ Salafi } & \multicolumn{2}{|c|}{ Khalafi } & \multicolumn{2}{|c|}{ Combination } \\
\hline & Big & Small & Big & Small & Big & Small \\
\hline Name & $\begin{array}{l}\text { Miftahul } \\
\text { Huda }\end{array}$ & $\begin{array}{c}\text { Asy- } \\
\text { Syahidiyah }\end{array}$ & Al-Furqon & Persis & Suryalaya & Ar-Riyadh \\
\hline Year Founded & 1967 & $1960 \mathrm{~s}$ & 1992 & 1979 & 1905 & 1930s \\
\hline Founder & $\begin{array}{l}\text { KH. Choer } \\
\text { Affandy }\end{array}$ & $\begin{array}{c}\text { KH. Syuhada } \\
\text { Al-Murtazi }\end{array}$ & Muhammadiyah & Persis & $\begin{array}{c}\text { Syech Abdullah } \\
\text { Mubarok }\end{array}$ & $\begin{array}{c}\text { KH. } \\
\text { Fachruddin }\end{array}$ \\
\hline Present Kiyai & $\begin{array}{l}\text { KH. Asep } \\
\text { Maoshul } \\
\text { Affandy }\end{array}$ & KH. Alfaryzant & $\begin{array}{l}\text { KH. Asep } \\
\text { Hidayat, Lc. }\end{array}$ & $\begin{array}{l}\text { Ust. Cece } \\
\text { Syamsudin }\end{array}$ & $\begin{array}{c}\text { KHA. } \\
\text { Shohibulwafa } \\
\text { Tajul Arifin }\end{array}$ & $\begin{array}{c}\text { KH. Asep } \\
\text { Bakhtiar Rifai }\end{array}$ \\
\hline $\begin{array}{c}\text { Amount of } \\
\text { Santri }\end{array}$ & $2500 \mathrm{~s}$ & 20 & 356 & 250-an & 2175 & $400 s$ \\
\hline $\begin{array}{c}\text { Amount of } \\
\text { Teacher }\end{array}$ & 89 & 1 & 60 & 50 & 172 & $100 \mathrm{~s}$ \\
\hline $\begin{array}{c}\text { Amount of } \\
\text { School }\end{array}$ & - & - & - & 1 & 3 & 1 \\
\hline $\begin{array}{l}\text { Amount of } \\
\text { Madrasah }\end{array}$ & - & - & 3 & 1 & 3 & 1 \\
\hline $\begin{array}{c}\text { Amount of } \\
\text { Higher } \\
\text { Education }\end{array}$ & $\begin{array}{c}1 \text { (Ma'had } \\
\text { Aly) }\end{array}$ & - & - & - & 2 & - \\
\hline $\begin{array}{c}\text { Amount of } \\
\text { University } \\
\text { Student }\end{array}$ & $100 \mathrm{~s}$ & - & - & - & 684 & - \\
\hline $\begin{array}{l}\text { Amount of } \\
\text { Lecturer }\end{array}$ & 10 & - & - & - & 152 & - \\
\hline Cooperation & Exist & - & - & - & Exist & - \\
\hline Workshop & Exist & - & - & - & Exist & Exist \\
\hline Rice Field & Exist & & & & Exist & \\
\hline Radio & Exist & & & & Exist & \\
\hline $\begin{array}{c}\text { Aid of } \\
\text { Government }\end{array}$ & Exist & - & Exist & Exist & Exist & Exist \\
\hline
\end{tabular}

\section{Roles of Pesantren in the Development of Village}

\section{a. Kinds of Development}

Not all kinds of development can be done by the pesantrens. Such is because there are things outside the abilitiy of pesantren to do. Political development is an example. The current stream of political situation of the Republic of Indonesia gave no chance for pesantrens to do political development. Euphoria of Reformation paved the way to political liberties. To play political role will bring the religious adherents (ummah) into conflict. Again, talking about politics today is a taboo, moreover if it is talked by a religious institution like pesantren which is appropriately neutral.

It is clear in the field being research that there is no one can say about politics and pesantren whether it is said by the government, the pesantrens, even the santris. To interview respondents on political topics is an unfruitful business.

As a result, beside that all people denied to be interviewed on politics, a list of question being offered to the respondents is responded by 'cold' responses. To the question no. 41, saying "How is pesantren's role in the development of politics in rural areas?", the majority of the answers is rightly even, i.e. average (123). The answers of positive and negative are not really significant to be compared for it is precisely the same if it is combined between the positive (72) and the negative (57) answers. 
So also in the development of ideology. Here pesantren has no active role. Such is because Indonesian national situation is not really stable. There are so many popular resistances to the government's flatforms. Still being Indonesians, it is may be the rest of ideological development. Everybody is thinking about himself, it is what happening here. And the pesantren side stutterly followed the time in changing.

Nevertheless, in a matter of safety, pesantren is still a safest place to live in. Many still believed in pesantren, although the West regarded that pesantren is the nest of the terrorists. Belief in the safety of the pesantren is seen from so many people asked the pesantrens to reconcile their conflicts. It can be seen from the answer to the Question No. 61 saying, "How is pesantren's participation in reconciliation of social conflict?", the majority of answer is positive answer, that is 163 (very big 55 and big 108). While negative answers are only 44, slightly the same as neutral answer, that is, 45 .

Something which can be traced to the roles of pesantren in the development is to the areas of education, social, cultural, and eonomics. Beside those areas, pesantren had limitations to play significantly their roles.

\section{b. Educational Development}

The existence of pesantren in the middle of the community has a strategic meaning, for it can fit itself with the development of time and the need of the community. Pesantrens today open the schools (under the guidance of the Ministry of National Education, MONE) or madrasah (under the guidance of the Ministry of Religious Affairs, MORA). In Tasikmalaya, the pesantrens of combination like Pesantren Suryalaya had founded schools for a long time so that there are schools like SMP (Sekolah Menengah Pertama, Junior High School), MTs (Madrasah Tsanawiyah, Islamic Junior High School), MA (Madrasah Aliyah, Islamic Senior High School), SMK (Sekolah Menengah Kejuruan, Vocational High School); and Pesantren Ar-Riyadh Leuwisari had founded MTs and SMK. Meanwhile, a modern pesantren like Pesantren AI-Furqon Singaparna since the very beginning had provided madrasah (Islamic school), i.e. MTs and MA. A small modern pesantren like Persis Rajapolah which in the beginning had MTs, is now also has SMA Plus (Sekolah Menengah Atas Plus, Senior High School Plus). About how a pesantren established schools, the following is a result of an interview with the leader of the Pesantren Ar-Riyadh.

Mulai tahun 1972 pesantren ini dipimpin oleh saya. Karena dirasakan adanya perkembangan zaman, bahwa masyarakat lebih memilih sekolah daripada pesantren, saya pun membuat sekolah-sekolah formal: TK, Madrasah Diniyah, MTs, dan SMK. Dengan demikian ada yang ikut dengan Depag, ada pula yang ikut dengan Diknas. Alhamdulillah pesantren ini masih banyak santrinya. Sekarang yang mondok ada 120an santri. Kalau dihitung yang sekolah mah banyak.

[Beginning in 1972 this pesantren was led by myself. Because that there was a development of time, that society chose more to the schools than to the pesantrens, so I built formal schools: PreSchool, Religious Islamic Elementary School, Islamic Junior High School, and Vocational High School. So that there are some follow the MORA, and some follow the MONE. Praise be to God, this pesantren has still more students. Now, the students live in the pesantren are around 120s. But if we count the students study in the schools are much more double than that]. (Interview Code: F-1; Recorded Code: Written).

Traditional Pesantren like Miftahul Huda and Asy-Syahidiyah basically did not refuse such systems of school or madrasah, even though they did not found schools or madrasahs in their 
pesantrens. To anticipate, both pesantrens allowed their santris to follow National Test for Study Group (Kejar, Kelompok Belajar) to get the certificate of SMP (Kejar Paket B) or to get the certificate of SMU (Kejar Paket C). The existence of systems of madrasah, school and packaged study group in a pesantren like that proved that appreciation of modern phenomena is also answered by the pesantren itself. For that modernity is an undeniable transformation process. The following is an interview with one of the leaders of Pesantren Miftahul Huda.

Dina dasarna nu masantren di dieu lulusan sakola. Aya anu lulusan SD, SMP, bahkan aya oge anu lulusan SMA. Namung kecenderungan ayeuna seueur anu lulusan SMP. Janten atos sarakola di dieu mah. Tah kangge santri-santri anu teu acan gaduh ijazah formal, tiasa ngiringan penyetaraan ngangge Kejar Paket $A, B$, atanapi $C$. Modernisasi memang teu tiasa dihindarkeun. Da ti darieu oge seueur anu jadi caleg (calon legislatif), anu tangtos peryogi ijazah formal kangge daftarna.

[Basically, the students live in this pesantren are school graduation. Some are graduated from SD [Sekolah Dasar, Elementary School], SMP, and even also SMA graduation. But the trend is the students graduated from SMP. So, the santris are school graduation. Here, for the santris who had no formal certificate, can follow equalization by way of Package Study Group A, B, or C. Modernization cannot be denied. Because here there are people who become caleg (calon legislative, the next legislative member), which then need the certificate to be listed as valid]. (Interview Code: A-1; Recorded Code: PIC_0614-0615.AVI).

Modernization can be more apparent in a pesantren which has a higher education such as Pesantren Suryalaya having an IAILM (Institut Agama Islam Latifah Mubaraqiyah, Latifah Mubaraqiyah Institute for Islamic Studies) and STIELM (Sekolah Tinggi IImu Ekonomi Latifah Mubaraqiyah, Latifah Mubaraqiyah Academy for Economics). It also done by Pesantren Miftahul Huda, Manonjaya. Even though Pesantren Miftahul Huda has only three year diploma for Islamic Studies (called as Ma'had 'Aly) and not nationally standardized, but it is rightly an effort for educating its santris. Modernization through higher education is also admitted by the local government.

Sebetulnya modernisasi pesantren banyak juga yang dilakukan oleh pesantren sendiri. Sekarang ini mulai banyak pesantren yang menyelenggarakan pendidikan formal, baik sekolah atau madrasah. Bahkan ada juga pesantren yang sudah mendirikan perguruan tinggi seperti Suryalaya dan Cipasung. Dan ini pun sudah menambah, bahkan mungkin merupakan sebahagian besar perguruan tinggi di Kabupaten Tasikmalaya adalah berbasis pesantren.

[Actually, modernization of pesantren is also done by the pesantren itself. Now, there are a lot of pesantrens open formal educations, whether it is a school or a madrasah. Even there are also pesantrens such as Suryalaya and Cipasung which established higher education. And it adds, and even the most part of higher education in Kabupaten Tasikmalaya is based on the pesantrens.] (Interview Code: G-2; Recorded Code: PIC_1101-1102.AVI).

In general, the main role of pesantren is exactly in the area of education. It is said that one pesantren can produce tens, hundreds, or even thousands other pesantrens by way of established by the alumni. Here it is clear that pesantren can be participated in literacy and national program of education. The following is an interview with an alumnus who himself now becomes Pesantren Leader and also is Deputy Chief of Local Parliament of Kota Tasikmalaya. 
Jadi awal ceritanya, ayah saya, pendiri Pesantren Bahrul Ulum, yang bernama K.H. Bustomi mondok di Pesantren Sukamanah, pahlawan nasional K.H. Zaenal Mustofa. Ketika ayah saya dengan K.H. Ruhiyat Cipasung mau ikut ke medan juang, tiba-tiba dilarang oleh K.H. Zaenal Mustofa. Mereka berdua disuruh untuk membina masyarakat. Akhirnya keduanya sama-sama kembali ke daerah. ... Nah Uwa Choer Affandy yang berguru ke ayah saya juga mau berangkat ke Jakarta untuk bisnis. Ayah saya dan Uwa beristikharah dulu, hasilnya jangan. Maka Uwa pun mendirikan pesantren di Manonjaya. Saya pun mesantren di Uwa. Saya pun meneruskan pesantren ayah saya. Jadi tradisi pesantren adalah tradisi turun menurun dari guru ke murid dalam memerangi kebodohan.

[The story begins with my father, the founder of Pesantren Bahrul Ulum, named K.H. Bustomi studied in Pesantren Sukamanah, led by the national hero K.H. Zaenal Mustofa. At that time, my father with K.H. Ruhiyat Cipasung would go for struggle for the Independence, suddenly prohibited by K.H. Zaenal Mustofa. They both are commanded to preach the society. Finally, they both came back to their hometown.... So Uwa Choer Affandy who studied to my father and wanted to go to Jakarta for making money... My father and Uwa prayed for the choice given by God (istikharah) first, and the result was not to go. Then, Uwa established a pesantren in Manonjaya. I also studied in Uwa's pesantren. And then I was commanded to continue my father's pesantren. Hence, pesantren is a genealogic tradition from teacher to student in making war to foolishness]. (Interview code: H-2; Recorded Code: PIC_1120.AVI).

A local government for National Education viewed pesantren as a potential for subject of nine year compulsory education. The following is an interview with Head Section of Junior High School of the Office of Education of Kabupaten Tasikmalaya.

Kami di sini, di Dinas Pendidikan Kabupaten Tasikmalaya ini ada mempunyai program Penyelenggaraan Kelompok Belajar Paket B setara SMP pada Pesantren Salafiyah. Sasarannya adalah usia wajib belajar Sembilan tahun, yaitu 13 sampai 15 tahun. Tetapi tidak menutup kemungkinan yang 18 tahun pun diambil sebagai murid. Gurunya juga kami rekrut dari kalangan pesantren sendiri. Dana pun kami sediakan untuk honor tutor dan alat tulis. Program ini kami namakan sebagai program wajar santri 'wajib belajar Sangkan anak ngarti Terampil Religius Islami.'

[We, here, in this Office of Education of Kabupaten Tasikmalaya have a program for conducting Study Group Package B equivalent Junior High School to Traditional Pesantrens. The targets are the children in the age of compulsory education, that 13 until 15 years old. But there is also a possibility that someone at the age of 18 is also taken as a student. The teachers are recruited from the pesantrens. The funds are also provided for the allowances of the tutors and for the stationaries. This program is named as the program of WAJAR SANTRI (wajib belajar Sangkan anak ngarti Terampil Religius Islami, compulsory education in order that the children understand, skillful, religious, Islamic)]. (Interview Code: G-3; Recorded Code: PIC_1103-1106.AVI).

It is admitted by the pesantrens of combination, that by providing formal education and using various languages such as Bahasa Indonesia, Arabic, or English, would bring to elevate santri's achievements. The following is a quotation of an interview with the leader of Pesantren Bahrul Ulum who is an alumnus of the Pesantren Miftahul Huda.

Di sini dulunya salafi, terus ada sekolah, yaitu SMP Islam. Ayah saya melihat masa depan. Sekarang ada TK, SMP, Tsanawiyah, bahkan Aliyah. Sekarang ada ide untuk mendirikan perguruan tinggi. Prestasi pesantren ini sekarang adalah juara ketiga tingkat nasional membaca 
kitab. Kalau se-provinsi kalah Miftahul Huda. Mohon maaf, karena memang kita mengajarkan pelbagai bahasa, Bahasa Indonesia, Inggris dan Arab. Di Miftahul Huda kan masih dominan bahasa Sunda, bahasa lokal.

[Here [this pesantren] for the first time was traditional, and then there was a school, i.e. Islamic Junior High School. My father had future outlook. Now there are Pre-School, Junior High School, Islamic Junior High School, and even Islamic Senior High School. Now there is an idea of establishing a university. The achievement of this pesantren today is the third position of national championship on reading Arabic text. In the provincial tournament, Miftahul Huda was beaten by us. Excuse us, because we teach many kinds of languages here, such as Bahasa Indonesia, English, and Arabic. In Miftahul Huda the dominant language is Sundanese, a vernacular.] (Interview Code: H-2; Recorded Code: PIC_1120.AVI).

By viewing an expanded development to the combinative pesantrens it is showed that the responses of the society to pesantren-with-school or pesantren-with-madrasah were very good. In turn, the community was felt that today pesantrens can give appropriate answer to modernity, i.e. life skill combined with happiness life (in religion). Concerning this, the following is a saying of an officer at the Office of Religious Affairs Department of Kabupaten Tasikmalaya.

Terhadap pesantren, Depag telah mengadakan program beasiswa santri untuk melanjutkan ke perguruan tinggi. Jadi mereka yang berprestasi di pesantren yang ada sekolah SMA atau Aliyahnya, yang rankingnya 1, 2, dan 3 bisa mendapatkan beasiswa ke universitas-universitas negeri. Kemudian ada lomba membaca kitab kuning. ... Nah untuk kasus Kabupaten Tasikmalaya, pesantren-pesantren yang mendapatkan beasiswa atau menjuarai lomba-lomba tersebut biasanya mendapat apresiasi lebih dari masyarakat, banyak santri baru yang berdatangan, meningkat secara signifikan.

[To the pesantrens, MORA had a program of scholarship for the santris to continue further education to universities. So, they are who have achievements in the pesantrens which have Senior High School or the Islamic one, who the ranks are 1, 2, and 3 can get scholarships to public universities. Then, there is also a tournament of reading Arabic text.... And for the case of Kabupaten Tasikmalaya, the pesantrens which can get scholarships or became the champions of the tournaments were usually appreciated much from the society, to this there would be coming more students, significantly raised.] (Interview Code: G-4; Recorded Code: PIC_1107-1111.AVI).

Beside with the way of formal education such as schools or madrasahs, pesantren were also known as non-formal vocational education. This kind of education is not only for the students live in there, but also for the community around it. Hence, the society had not only been taught by religious doctrines, they had also been trained by vocational things. The following is the response of the Chief of Sub-Section of Religious Affairs of the Government of Kabupaten Tasikmalaya.

Selain kepada santri, pesantren juga mendidik masyarakat dengan cara majlis ta'lim, remaja mesjid, dan sebagainya. Ada yang mingguan, ada yang bulanan. Ada yang malam diselenggarakannya, ada yang siang. Untuk program-program pelatihan ketrampilan, pesantren biasanya bekerja sama dengan pihak lain, dengan pemerintah atau lembaga swadaya masyarakat. Dengan pemerintah juga ada yang dengan dinas pertanian, dinas peternakan, dinas pemberdayaan masyarakat, atau dinas-dinas lainnya.

[Beside to the santris, pesantrens also taught the society by way of religious-learning circle, mosque youth, etc. Some activities are weekly, some others monthly. There are also evening 
activities and day activities. For vocational training programs, pesantrens are usually cooperated with others, with the government or other social institutions. With the government there are offices of agriculture, of empowering society, or any other offices.] (Interview Code: G-2; Recorded Code: PIC_1101-1102.AVI).

The most significant thing to educate rural society done by pesantrens is to liberate the society from illiteracy. It is seen how pesantrens play big role (152: very big 51 and big 101) in respondent's answer to the Question No. 74 saying, "How is the role of Pesantren in eradicating illiteracy (Packaged Study Group A, B, etc.)?" Whereas the answers undermining the meaning of pesantren in this sense is not significant, i.e. only 48, lesser than neutral answers (52).

\section{c. Economic Development}

Pesantrens being studied here, not only bring Tasikmalaya into "santri town," but also can give economic life of the society around them, by establishing a cooperation or even a financial institution such as Baitul Mal wa Tamwil (BMT, the House of Treasury) giving much help to the society. Moreover, pesantrens also became the centers of economic life of the society. There are a lot of people taking advantage economically to the pesantrens. Book shops, food shops, boutiques, etc. mushroomed around the pesantrens. This, for example, is happened in Suryalaya. Every $11^{\text {th }}$ of Hijriyah months there is a Manakiban (praying together). At that time pesantren's circumstances were massively presented by retailers. The following is a result of an interview with the Head of the Secretariat of Pesantren Suryalaya.

Sekarang ini masyarakat dari segi ekonomi banyak warung, belum yang kejut, setiap bulan ada manakiban, ini sepanjang jalan berbagai pedagang. Belum tenaga kerja yang terserap. Tasawuf yang diajarkan dengan demikian tidak membuat masyarakat mundur. Kami telah membuktikan bahwa zuhud itu adalah mengalahkan dunia. Katanya zuhud tetapi bangunan batu semua. Tetapi bahwa zuhud itu tidak kalah dengan kekayaan.

[Today, economically society has more shops, not even the sudden ones, every month there is manakiban, along this road are the retailers. Not even the workers are absorbed here. The theosophy which is taught, then, not bring the society into backwardness. We prove that zuhud can beat the mundane life. We say it zuhud, but you can see that all the building are made by the rocks. We prove that zuhud is not beaten by wealthy.] (Interview Code: E-1; Recorded Code: PIC_0377.AVI).

This is also admitted by the Head of the Village around Pesantren Miftahul Huda. The following is his opinion.

Dengan adanya pesantren memang bermunculan tukang dagang, jadi semakin ramai. Masyarakat bisa berjualan hasil-hasil kebun, pisang goreng, pecel, yang tadinya nganggur bisa berjualan. Demikian juga tukang ojek bisa lebih sibuk kalau ada pertemuan-pertemuan pesantren. Kalau satu Muharram, apalagi, Miftahul Huda suka membuat acara. Orang-orang pesantren biasa konvoi.

[By the emergence of the pesantren there are also emerged retailers, so here is busier than before. The society can sell their farming products such as bananas, vegetables, so those who usually had no jobs, can regularly be the sellers. So also the motorist taxi can be busier if there are pesantren meetings. On the first of Muharram, is much more, Miftahul Huda usually has a 
program. Pesantren's people are convoy around the village.] (Interview Code: G-5; Recorded Code: PIC_1115-1118.AVI).

Beside to commercial sector, pesantrens also help the society in service sectors. Pesantren insiders acknowledge that when they built schools or madrasahs there were many workers absorbed, from the plumbers, cleaning service, cooks in the kitchen, until the most important employee in the learning processes, i.e. the teachers. Thus, the more the pesantren built a new school, the more workers were absorbed by the pesantren. Here is a quotation from an interview with a manager of Pesantren Ar-Riyadh, Leuwisari.

Ketika pesantren ini buka sekolah, banyak guru yang datang, tukang-tukang batu, dan para pedagang bermunculan. Mereka pada datang sendiri. Bukan hanya yang dekat, yang jauh juga ada. ... Di sini ada juga masyarakat yang menjadi ibu-ibuan para santri, yang menjadi tempat mereka makan. Karena santri sekarang sudah tidak sempat lagi masak sendiri. Kalau kita para pengelola, kiyai dan ustaz ya cari sendiri. Dari ceramah-ceramah, begitu. Jadi sekolah ini bukan untuk mencari untung, tetapi untuk memakmurkan pesantren, memakmurkan Islam.

[When this pesantren opened schools, there were many teachers coming, plumbers, and retailers were also coming. They came by themselves. Not even the nearer of the pesantren, the farther were also coming.... Here there were some of the inhabitants who became the mothers of the students, where the santris eat. For the santris today had no time anymore to make their food by themselves.... We are the managers, kiyai, and ustazs should make our living by ourselves. From the sermons, so to speak. So, this school is not for searching benefits, but for making the pesantren busy, for empowering Islam.] (Interview Code: F-2; Recorded Code: PIC_02990301.AVI)

Economic enhancement of the society through cooperation built by the pesantrens is an evidence of pesantrens' participation, especially in economic development of the society, whether it is for the interest of pesantrens' insiders or for the society around them. It can be seen by the emergence of cooperations of pesantrens (Kopontren, koperasi pondok pesantren) existed in the pesantrens in Kabupaten Tasikmalaya, like what happened in Pesantren Suryalaya.

In order to fulfill the needs of santris and pesantren insiders, Pesantren Suryalaya founded a cooperation called Koperasi Putera Bhakti in 1973. The management was run by the santris. 1979 the cooperation changed the name into Kopontren Suryalaya HIDMAT (Koperasi Pondok Pesantren Suryalaya Hidup Masa Thoreqat). From such a change, cooperative scope was extended whether it is for the students or the tarekat's followers living in the rural areas.

The units of cooperation built within the Kopontren HIDMAT are:

1. Merchandising Unit: Retail shop, Taylor.

2. Cooperative Unit: Post and Telecomunication Shop, Agent of oil/LPG gas, Electric bill service, Gas station, credit for moving retailers, radio making.

3. Social Business: Project for Sheep Breeding, Social Fund (From Satu Abad Pondok Pesantren Suryalaya, 2005).

How big the interest of pesantren insiders and the community to elevate economic life, there is an effort to establish a House of Treasury (Baitul Mal) of Suryalaya, working on credit enterprise, permanent donator, zakat (poll tax), and charities like infaq and waqf. This was also the case of 
Pesantren Miftahul Huda cooperated with the government of West Java. All these proved how big the pesantrens take parts in advancing the economy of the society.

Nevertheless, more or lesser the impact of the pesantrens to the economy of the society was not the same. It can be seen from the open or not the pesantren was. For instance, in a closed pesantren like Al-Furqon, all about food of the santris were organized by the pesantren. There was also a semi-open pesantren, meaning that pesantren only managed meals twice a day, the rest was given to the students for buying to the retailers around the pesantren. It happened in Pesantren Miftahul Huda and Persis Rajapolah. There was also offered totally to the students to cook for themselves, such as what happened in Pesantren Asy-Syahidiyah. There was also a pesantren submitting the problems of food to the society and students themselves.

From the size of the pesantren, it is clear that each pesantren has its own potentials to give economic impact on the society. The bigger the pesantren gives the more job opportunities to the community. Such is because there always be more additional rooms, beds, school buildings, etc. Something hoped by the society, then, is that the pesantren would always give the jobs for the community around it. The following is the opinion of the Head of the Village closed to Pesantren Miftahul Huda.

Dari dulu Uwa selalu bilang, tolong bantu Pak Kuwu....Saya pun selalu minta bantuan kepada para kiyai untuk memasyarakatkan kewajiban pajak. Saya pun selalu berpesan, kalau ada proyekproyek tolong libatkan masyarakat. Karena tidak enak kita hidup dengan masyarakat, tetapi tidak mempekerjakan mereka. Jadi kita saling bantu, begitu. Biar bagaimanapun kami ini penduduk asli sini, kalau santri kan banyaknya orang jauh, mereka hanya di sini untuk mesantren. Jadi harus kerja sama, begitu.

[Since the very beginning Uwa had said, please help the Head of the Village...I always ask to the kiyais to socialize the obligation to pay taxes. I also ordered, if there are some projects, please involve the society. Because it is not healthy to live with the community, but at the same time not involving them in the works of the pesantren. So that we help each other, like that. Whatever we are, we are indigenous people. Santris came mostly from faraway, they were in here to study. So that we should cooperate each other, so to speak.] (Interview Code: G-5; Recorded Code: PIC_1115-1118.AVI).

Although the participation of pesantrens in the economy of the community was not big enough, but the existence was there, felt by them. To the Question No. 51 saying, "How is the participation of the pesantren in elevating economic life of the society?" the majority of the respondents answered positive (126: 35 very big and $91 \mathrm{big}$ ). While they who answered negative were only 38 respondents (25 less big and 13 not big), smaller in number than those who answered neutral (88).

\section{d. Social Development}

In 1971 Pesantren Suryalaya helped government's program in rehabilitating drug addicts and juvenile delinquency. That effort was in line with government's code of Bakolak Inpres No 6 year 1971. The rehabilitation was through praying with the method of sufi order of Tariqat Naqsabandiyah Qadiriyah (TNQ) in order to get the youth back to the true way. This program was institutionalized in 1986 named as Youth House of "Inabah" (meanig 'getting back'). The continuation and extensivication of the doctrine were done through Suryalaya's branches of sufí orders and through the preachers coordinated by the branches. 
Such is one of the products of the pesantren to the young generation. Other pesantrens gave also their attention to the youth. By making them busy in good conducts, pesantren had eradicated the bad of juvenile delinquency. In fact, some santris, like those of Miftahul Huda, often swept to the places where bad habits were coming like pubs, bars, etc. This action is called as a manifestation of the concept of 'jihad' (meaning 'considerable struggle', Prophet Muhammad mentioned this for war against infidelity, including the passion). Perhaps it is an extreme action of the santris, for Indonesia is not an Islamic State. But possibly it is a mirror of political liberty in Indonesia. It is said by a student of Miftahul Huda, as follow.

Sweeping ke masyarakat untuk kemaksiatan memang suka ada di sini, untuk minuman keras, untuk yang tidak puasa. Itu program kita di sini. Tahun 2005, 2006, 2007, sebelum menginjak bulan Ramadhan, santri senior dan dewan kiyai merazia ke daerah Tasikmalaya, Manonjaya. Tahun 2008, yang kemarin, itu langsung ke pemerintah, ke polisi, tolong dirazia, kalang enggak, santri akan turun. Polisi langsung turun ke jalan. Tapi kalau tahun depan polisi tidak turun, santri yang akan turun. Ini bagian dari jihad. Kan kalau dibiarkan disebutnya dayus, membiarkan. Kalau tidak Allah akan murka. Pertama kan peringatan dulu, tidak semena-mena terus merazia.

[Sweeping to the society for eradicating bad habits were likely done here, for those who drink liquor, they who do not fast [within the month of Ramadan]. That is our program here. In 2005, 2006, 2007, before entering the fasting month, senior students and some kiyais boards swept to Tasikmalaya, Manonjaya. In 2008, the last one, we directly went to the government, to the police, saying, please remove bad habits on the streets, if not we will go down to sweep. And the police directly went to the streets. But if next year the police won't go down, the santris will. It is part of the jihad (struggle). For if we let them go it is dayus, ignore. If it is not done God will be angry. The first step is a warning, not directly grab, like that.] (Interview Code: A-4; Recorded Code: PIC_0606-0610.AVI)

To the Head of the Village, the concept of jihad with directly go down to the streets is not really agreed. Such is because it will invite a horizontal conflict. The following is an interview with the Head of the Village.

Dulu suka ada sweeping memang. Kalau tidak puasa diambilin. Tetapi biar bagaimanapun juga kami ini penduduk asli sini, tanah kelahiran. Kalau santri kan kebanyakan tamu, jadi harus menghargai. Jangan sampai terjadi bentrok fisik. Biar bagaimana juga tetap itu harus dijaga. Karena kita bagaimanapun juga penduduk asli. Jadi harus bisa menitipkan diri. Saya juga kalau merantau harus menitipkan diri. Jadi kalau kita mau gaya-gayaan ya pasti akan ada yang mukul.

[There were often sweepings really. They who did not fast were taken. But whatever we are, we are indigenous people here, this village is our hometown. The santris were mostly outsiders, so that they should admire us. Don't make a declaration of war. Whatever it is, it should be kept in mind. Because we are here native people. So the santris should be able to place themselves. I was myself if I went to outside of my hometown should be able to place myself. So, if we extreme ourselves there would be people who fight us.] (Interview Code: G-5; Recorded Code: PIC_11151118.AVI).

For Pesantren Al-Furqon Muhammadiyah, the concept of 'jihad' means the necessity to struggle in doing good conducts, in learning activities, for instance, or in any other positive activities. It is not surprising if from such a pesantren there were emerged national athletes, Olympic math and science, and any other achievements. Here is a quotation from an interview with one of managers of the Pesantren Al-Furqon. 
Seperti waktu bulan puasa, ada pesantren-pesantren yang keluar mencari orang-orang tidak puasa. Sweeping, gitu. Jihad, katanya. Kalau di sini kan tidak begitu ya. Ya biarkan saja. Kita juga heran apa yang dipelajari di sana. Pada prinsipnya pesantren sana juga sama, sebagai lembaga pengajaran. ... Jihad di sini ya belajar secara bersungguh-sungguh. Kita tidak merasa terpanggil untuk melakukan penyerangan-penyerangan. Perubahan yang diinginkan tidak harus secara radikal. Kita cari ilmu aja jihad. Ambil kotoran aja jihad. Kita berbakti kepada masyarakat juga jihad.

[Like in the fasting month, there are some pesantrens go outside searching the people who do not fast. Sweeping, like that. Jihad, they say. Here is not like that. Just let it go. We are surprised what is exactly learnt there [in such pesantrens]. In principle, those pesantrens are also same [with us], as a learning institution. ... Jihad here is to study seriously. We are not invited to do some offences. The idea of change should not be done radically. We search for knowledge is also jihad. Taking garbage from the street is also a jihad. We serve the community is a jihad too]. (Interview Code: C-3; Recorded Code: PIC_0358-0364.AVI).

Activities for women were also existed in the pesantren, even in a smallest pesantren as AsySyahidiyah. The activities are especially religious learning for women, but such women groups could be more than learning groups. As an example, we can see what is done by a women group in Pesantren Suryalaya which is called Ibu Bella. 'Bella' is the short from 'Beres Laku Lampah' (good conduct). This organization was founded on $6^{\text {th }}$ of September 1966. It worked on social field. Among the activities were: served the orphans, elder people, child rearing, mass circumcision, gave presents to the workers, complemented kitchen stuffs, educated pre-school children, founded cooperation, and gave hands to the unfortunate. (Satu Abad Pondok Pesantren Suryalaya, 2005).

Pesantren Miftahul Huda was also known for its charity to the community. Here is a quotation from an interview with the Head of Village Kalimanggis, Manonjaya.

Sosialnya bagus pesantren Miftahul Huda. Pesantren itu membagi-bagikan ke fakir miskin, karena mungkin dia sumbangannya lebih besar mungkin, saya tidak tahu. Bantuan-bantuan dari pusat disalurkan kepada masyarakat seperti hewan kurban, ke panti jompo, itu bagus. Jadi yang tidak mampu itu banyak dibantu oleh pesantren.

[Pesantren Miftahul Huda's social work is very good. The Pesantren gave to the poor, maybe the charity it had is bigger, I don't know. The aid from the central [government] was given to the society like the meat of led al-Adha, to elder people, that's good. So, the unfortunate was helped by the Pesantren.] (Interview Code: G-5; Recorded Code: PIC_1115-1118.AVI).

Here pesantrens was really viewed as a social institution. For even an unfortunate could study in a pesantren. Here is a quotation of an interview with the Head of Sub-Division of Religious Affairs, Kabupaten Tasikmalaya.

Santri itu diasramakan, dipondokkan. Tetapi kadang-kadang ada santri-santri yang tidak mampu. Itu beratnya pesantren. Dari mulai makan dan menginap kan ditanggung pesantren. Karena sifatnya beramal, ikhlas beramal, ya dijalani juga. Ya kalau sekolah di perguruan tinggi kan kalau tidak bayar ya tidak bisa belajar. Tetapi kalau di pesantren ya sepanjang dia mau ya masih bisa belajar. Di situlah nampak jelas bahwa pesantren sebagai lembaga sosial. 
[Santri are barracked, lived in pesantrens. But there are some unfortunate students. That is the difficulty of pesantrens. From eating to living they are guaranteed by pesantrens. Because its nature of charity, sincere charity, pesantrens are go on. It is clear that in a university if you have no money you can't go to study. But in pesantrens, you can live there as long as you can if you want to study. Here then it is clear that pesantren is a social institution.] (Interview Code: G-2; Recorded Code: PIC_1101-1102.AVI).

Another thing to be cited in the participation of pesantren to the environment is about cleanliness. Of the Question No. 56 saying, "How is the participation of pesantren in cleaning the environment?" there were positive answers as the majority (128: 31 very big, 97 big). Negative answers were very small (59: 35 less big and 24 not big), smaller than the neutral answers (65).

\section{e. Cultural Development}

Pesantren is a place where the talents of the youth grow up. Because they lived and grew in pesantren, their talents sprang like mushroom in the winter. Here is clear that pesantren can be a development agent. Among the developed things in cultural development are contest of the Qur'an, religious songs and music, and any other contests.

Santris who are talented in religious affairs very often participated in the Qur'anic contests celebrated by Indonesian government nationally, regionally, even locally. In such activities the talented students in tarannum (musicalities) of reciting the Qur'an can be participated in the contest of Qira'at al-Qur'an; they who clever in understanding the Qur'an can be participated in the contest of Tafhim al-Qur'an; they who can memorize the Qur'an can be active in the contest of Tahfiz al-Qur'an; they who are talented in calligraphy can follow the contest of Calligraphy of the Qur'an; they who are great in reading Arabic text can also follow the contest; and so on.

In the world of entertainment such as singing, traditional and combination pesantrens had usually groups of Arabic music (Qasidah). Modern pesantrens, on the other hand, had Arabic song (Nasyid) groups or even a band.

In turn, all talents can give Islam more shining in many places. Musicalities of the Qur'an are done by santris before an opening of a program; calligraphy is usually made to adorn mosques and other places; Qasidah and Nasyid are frequently showed in the end year of the study for santris farewell party or in the ceremony of marriage, or in any other programs. In Pesantren Persis there is always a humor show combined with bamboo music, named 'calung'. For such pesantrens with radio station as Pesantren Suryalaya and Miftahul Huda, the show is everyday, for they should have time for various programs, whether they are religious, educational, or even entertaining programs. For instance, Radio Inayah FM of Suryalaya had percentage of programs as follows: Dangdut songs (30\%), Western Pop songs (10\%), Indonesian Pop songs (25\%), Ethnic (10\%), Religion (20\%), and Information (5\%). (From Satu Abad Pondok Pesantren Suryalaya, 2005).

The function of radio for Pesantren Suryalaya is especially for the mission of propagation to various places in West Java. Such is because not everyone can come to the pesantren for listening to the kiyai's sermons. The same rationale was uttered by an announcer of Rasimuda (Radio Siaran Miftahul Huda, Miftahul Huda Radio Station) FM. The difference is the percentage: Entertainment (10\%), News (20\%), Religious Studies (70\%) (From an interview with an announcer of Rasimuda, Interview Code: A-3. Recorded Code: PIC_0716-0719.AVI). 
In essence, Radio Rasimuda was directed to channelize communication between the pesantren and the Muslims, especially whose who symphatized with the pesantren.

In short, through their programs, pesantrens had helped rural society in advancing its educational, economic, social, and cultural development. All that is based on the qualities the Muslims should have, that is, being the servant of God (Abdullah) and the caliph of God. Hence, every Muslim can do good and right to the Creator (hablum minallah) and to the humans (hablum minannas).

\section{CONCLUSION}

There are some statements to be concluded from this study:

1. Pesantrens had less their roles in the developments of ideology, politics, and safety of the community of the villages. For they are optional. Here pesantrens only gave their participation to pesantren insiders, and not to the outsiders.

2. For development of education, pesantrens had given many roles to be considered, for it is in essence an educational institution. So, everything educational, pesantrens can give its roles as hard as it can. For they who are ready to learn, pesantrens established madrasahs, schools, pre-school, and universities. For they who only wanted to get certificate, pesantrens also had the program of package study group (A, B, and $C)$. For they who wanted to continue to a higher education, pesantrens provided such scientific activities as discussion, seminar, workshop, etc. For they who did not come to pesantrens, pesantrens were ready to send their kiyais, ustazs, or their santris to teach or to preach. So also, some pesantrens had published magazines; and so on.

3. Even though pesantrens were not economic institution, but it is not denied that pesantrens had been participated in economic development. That is, for example, pesantrens can make livings to the teachers, managers, technical workers; can absorbe plumbers; can produce retailers (food, books/religious books, stationery, clothes, etc.); can found cooperation; can build gas station, can give a hand in capital for small scale enterprise, etc.

4. Pesantrens are not only an institution of education, but they are also social institutions. For social development, pesantrens had struggle for the orphans and elderly people; performed mass circumcision; scholarship for the unfortunate students; gave hands to the least advantage; gave health services; provided rehabilitation of drug addicts; cooperated with the society for societal needs such as providing irrigation, bathroom, toilet; doing cleanliness; etc.

5. As a subculture, pesantrens also took part in developing culture. Here, pesantrens provided training and contest of the Qur'an (musicalities, memorizing, understanding, calligraphy, etc.); voice art (nasyid); Arabic music; traditional and modern music; established radio, etc.

6. Religious matters are really obligation for pesantrens to solve. Here such social programs as natality, mortality, and marriage should be help by religious institutions like pesantrens. Besides, pesantrens were also always ready to send their teachers to religious sermons regularly, on special occasions, or on social/family parties. Religious guidance is not only based on religious books but also based on experience. Here, then, pesantrens were ready to serve courses of pilgrimage (hajj) and umrah.

7. Vocational trainings were also done by the society. Such is because pesantrens had places and funds for vocational education. Such vocational trainings are performed especially for agriculture and small industry. Vocational trainings on agriculture are, among others, training for cultivating great rice, sheep breeding, cultivating jarak tree for 
biodiesel, etc. In industrial field, vocational trainings such as sewings, embroidery, production of tahu/tempe, and extracting oil of tree were done by pesantrens for the society to develop economic life of rural society.

Table 3. Role and Participation of Pesantren in Rural Development

\begin{tabular}{|c|c|c|}
\hline No. & Role & (2) \\
\hline 1. & Education & $\begin{array}{l}{ }^{*} \text { formal school } \\
\text { * } \text { higher education } \\
\text { * non-formal package of education } \\
\text { * religious school }\end{array}$ \\
\hline 2. & Economy & $\begin{array}{l}\text { * job (teacher, plumber, etc.) } \\
\text { * agriculture product (rice, fish, etc.) } \\
\text { * merchandise } \\
\text { * small scale industry } \\
\text { * shop } \\
{ }^{*} \text { capital }\end{array}$ \\
\hline 3. & Social & $\begin{array}{l}\text { * orphanage } \\
\text { * serve elder people } \\
\text { * child rearing } \\
\text { * mass circumcision } \\
\text { * scholarship } \\
\text { * fund for dissaster } \\
\text { * health service } \\
\text { * serve people coming to pesantren } \\
\text { * drug addict rehabilitation } \\
\text { * give side dish before fasting } \\
\text { * give presents in the celebration of led al-Fitri } \\
\text { * give meat in the celebration of ied al-Adha } \\
\text { * work together with the society } \\
\text { * preserve irrigation/water supply } \\
\text { * preserve bathroom, for washing, and toilet } \\
\text { * keep the environment clean }\end{array}$ \\
\hline 4. & Religious & $\begin{array}{l}\text { * regular teaching } \\
\text { * admonition in a party } \\
\text { * aid for the dead people } \\
\text { * preaching in Islamic feast calendar } \\
\text { * training for pilgrimage (haij) and umrah }\end{array}$ \\
\hline 5. & Cultural & $\begin{array}{l}\text { * contest for the Qur'an (reciting, memorizing, understanding, } \\
\text { calligraphy, etc.) } \\
\text { * voice art (nasyid) } \\
\text { * Arabian music } \\
\text { * traditional and modern music } \\
\text { * } \text { radio }\end{array}$ \\
\hline 6. & Vocational Training & $\begin{array}{l}\text { * sheep breeding } \\
\text { * socialization of great germ of rice } \\
\text { * socialization of jarak kitchen } \\
\text { * job training } \\
\text { * agriculture training } \\
\text { * training for producing tahu/ tempe } \\
\text { * training of applied technology }\end{array}$ \\
\hline
\end{tabular}

\section{Implication of Study}

Pesantrens as community development are not new phenomena. For a long time pesantrens were known as agents for developing rural areas. Pesantrens are community based schools. The difference is that today the kind of advancement carried by pesantrens is more modern. And pesantrens showed that modernity is not a disaster, it is blessing. Everything is religious if it is touched by pesantrens, including development. 
This study shows that Boeke's opinion (1942) that there was 'dualism' which cannot be roughly combined but separated diametrally with economic life in Indonesia, that is, tradisional and modern; was not happened in pesantrens.

It is better to study pesantrens with transitional (from traditional to modern) society as said by Abraham (1991) or 'prismatic' society as mentioned by Riggs (1985). Such is because that in pesantrens today, various functions which firstly centered in one hand were now diverged into specialization, heterogenous, and overlapping. The potrait of the society in pesantrens is transitional potrait: towards modernity without letting the tradition down.

\section{Suggestion}

Based on above conclusion and implication, there are suggestions here to elucidate:

1. For the sake of optimalization of functions and roles of pesantrens in the development, there should be exploratory effort or even formulated the pattern of modern management which can be applied for developing pesantrens. This is needed especially to anticipate the development of society which is going to be globalized.

2. Willingness and openness of the pesantren leaders (kiyai) and managers to empower all existing potentials in their environment, especially through the elevation of quality of human resources in order to play more role in developing the community to the just and prosperous society.

3. Connected to the above point (2), it is needed to promote the more open climate to accept all positive and constructive inputs for developing pesantrens, both in building their qualities and constructing their institutional roles.

4. Pesantrens were involved in the processes of development of society, especially in rural areas. There should be training and guidance for knowledge and managerial skill whether it is for pesantrens' leadership, institutional development, or for the interest of the society.

5. The pattern of recruitment of leadership which is usually internal, taking from insiders, should be expanded to outsiders as long as it is not opposed to the main mission of the pesantrens themselves. 


\section{References}

Abdullah, Taufik. (1986). "The Pesantren in Historical Perspective," in Abdullah, Taufik and Siddique, Sharon (eds.), Islam and Society in Southeast Asia, Singapore: Institute of Southeast Asian Studies.

AMIDA (Himpunan Alumni Miftahul Huda), (2008), Draf Musyawarah Kerja (Muker) Ke-30 Tahun 1429 H/2008 M, Tasikmalaya: Manonjaya.

Atlas Provinsi, 2006.

Badan Pusat Statistik Kabupaten Tasikmalaya. (2008). Kabupaten Tasikmalaya Dalam Angka.

Badan Pusat Statistik Tahun 2004, (2004). Hasil Pemutakhiran dalam rangka Pemilihan Presiden Tahun 2004.

Boeke J.H.. (1942). The Structure of Netherlands Indian Economy, New York; Institute of Pacific Relations.

Chua, Yan Piaw (2006). Kaedah Penyelidikan, Kuala Lumpur: Mc Graw Hill.

Depag R.I., (2006). Statistik Pendidikan Agama dan Keagamaan Tahun Pelajaran 2005-2006, Jakarta: Bagian Data dan Informasi Pendidikan, Direktorat Jenderal Pendidikan Islam, Departemen Agama.

Depdikbud. (1995). Kamus Besar Bahasa Indonesia, Jakarta: Balai Pustaka.

Dhofier, Zamakhsari, (1983). Tradisi Pesantren, Kajian tentang Pandangan Hidup Kiyai, Jakarta: LP3ES, Jakarta.

Korten, David C. and Alfonso, Felipe B. (eds.),. (1981). Bureaucracy and the Poor: Closing the Gap, Singapore: McGraw-Hill International Book Company, Copyright by Asian Institute of Management, Makatai, Metro Manila, Philippines.

Laporan Bulanan Maret 2009. (2009). Tasikmalaya: Pondok Pesantren Miftahul Huda Manonjaya.

Madjid, Nurcholish, dkk. (ed.). (1984). Ensiklopedi Islam, Jilid IV, Jakarta: PT. Ichtiar Baru Van Hoeve.

Mansurnoor, lik Arifin. (1990). Islam in an Indonesian World: Ulama of Madura, Yogyakarta: Gadjah Mada University Press.

Materi Rapat Anggota Tahunan (RAT) Kopontren Hidmat Suryalaya Tahun Buku (2008), Tasikmalaya: Suryalaya.

Menejemen Tahapan Proses Pencapatian Target Da'wah TQN, (2008) Tasikmalaya: Pondok Pesantren Suryalaya.

Morrish. (1978). Ivor, The Sociology of Education: An Introduction, Unwin Education Books, Series Editor: Ivor Morrish, London: George Allen \& Unwin. $2^{\text {nd }}$ edition. 
Patton, Michael Quinn. (1990). Qualitative Research and Evaluation Methods, 3rd edition, London: Sage Publications.

Pengembangan dan Peningkatan Dakwah, Tabligh, Ceramah (Pengajian Manakiban), (2005) Tasikmalaya: Pondok Pesantren Suryalaya.

Pikiran Rakyat, surat khabar harian, 15 April 2009.

Pondok Pesantren Miftahul Huda, (2008), Leaflet, Tasikmalaya: Yayasan Pesantren Miftahul Huda.

Profil Miftahul Huda, (2009), Tasikmalaya: Pondok Pesantren Miftahul Huda Manonjaya.

Program Pengembangan Agribisnis Melalui Penerapan Teknologi Tepat Guna di Lingkungan Pondok Pesantren Suryalaya, (2009), Tasikmalaya: Koperasi Pondok Pesantren HIDMAT Suryalaya.

Riggs, Fred W. (1964). Administration in Developing Countries: The Theory of Prismatic Society, Boston: Houghton Mifflin Company.

Risalah Sosialisasi Bibit Padi Hibrida "Bernas", (2009), Tasikmalaya: Koperasi Pondok Pesantren HIDMAT Suryalaya.

Salkind, Neil J. (2000). Exploring Research, 4th edition, New Jersey, US: Prentice Hall.

Satu Abad Pondok Pesantren Suryalaya: Perjalanan dan Pengabdian 1905-2005, (2005) Tasikmalaya: Yayasan Serba Bakti Pondok Pesantren Suryalaya.

Sejarah dan Perkembangan Pendidikan Formal di Lingkungan Yayasan Serba Bakti Pondok Pesantren Suryalaya, (2007). Tasikmalaya: Yayasan Serba Bakti Pondok Pesantren Suryalaya.

Stalcup, R. J. (1968). Sociology and Education, Columbus, Ohio: C. E. Merrill.

Tohir Sh., H. Asep Moh. (ed.) (1999). Sisi Lain Pesantren Miftahul Huda, Tasikmalaya: Yayasan Pesantren Miftahul Huda.

Unang Sunardjo, RH., SH. (1995). Menelusuri Perjalanan Sejarah Pondok Pesantren Suryalaya, Tasikmalaya: Yayasan Serba Bakti Pondok Pesantren Suryalaya. 


\section{Attachment}

\section{Codes of Interviews}

\begin{tabular}{|c|c|c|c|c|c|}
\hline No. & $\begin{array}{c}\text { Code of } \\
\text { Interview }\end{array}$ & Recorded Code & Respondents & Position & Place/ date of interviews \\
\hline 1. & $A-1$ & $\begin{array}{l}\text { PIC_0614-0615.AVI } \\
\text { and PIC_1676- } \\
\text { 1699.AVI }\end{array}$ & KH. Asep Tohir Sh. & Kyai & $\begin{array}{l}\text { Miftahul Huda, Manonjaya, } \\
18 \text { Oktober } 2008 \text { and } 1 \text { Mei } \\
2009\end{array}$ \\
\hline 2. & $A-2$ & $\begin{array}{l}\text { PIC_0744-0746.AVI } \\
\text { and } \\
\text { PIC_0759-0760.AVI } \\
\text { And PIC_1700- } \\
\text { 1707.AVI }\end{array}$ & Wawan Al-Farisi & Santri, Vice President & $\begin{array}{l}\text { Miftahul Huda, Manonjaya, } \\
19 \text { Oktober } 2008 \\
\text { And } 1 \text { Mei } 2009\end{array}$ \\
\hline 3. & $A-3$ & PIC_0716-0719.AVI & Rasyid, Ricky & Santri, Radio Announcer & $\begin{array}{l}\text { Miftahul Huda, Manonjaya, } \\
18 \text { Oktober } 2008\end{array}$ \\
\hline 4. & $A-4$ & PIC_0606-0610.AVI & $\begin{array}{l}\text { Ricky Ahmad } \\
\text { Taufik }\end{array}$ & Santri, Ma'had 'Aly & $\begin{array}{l}\text { Miftahul Huda, Manonjaya, } \\
18 \text { Oktober } 2008\end{array}$ \\
\hline 5. & $A-5$ & PIC_0782.AVI & & Santri eating porridge & $\begin{array}{l}\text { Miftahul Huda, Manonjaya, } \\
19 \text { Oktober } 2008\end{array}$ \\
\hline 6. & $A-6$ & PIC_0743.AVI & & Santri, Regiment (Muharrik) & $\begin{array}{l}\text { Miftahul Huda, Manonjaya, } \\
19 \text { Oktober } 2008\end{array}$ \\
\hline 7. & A-7 & PIC_0773.AVI & & Santri eating at cafeteria & $\begin{array}{l}\text { Miftahul Huda, Manonjaya, } \\
19 \text { Oktober } 2008\end{array}$ \\
\hline 8. & $A-8$ & PIC_0747-0751.AVI & $\begin{array}{l}\text { Agus Rahmat } \\
\text { Hidayat }\end{array}$ & $\begin{array}{l}\text { Santri, Head of Section of } \\
\text { Education }\end{array}$ & $\begin{array}{l}\text { Miftahul Huda, Manonjaya, } \\
19 \text { Oktober } 2008\end{array}$ \\
\hline 9. & B-1 & Written & Kyai Al-Faryzant & Kyai & $\begin{array}{l}\text { Asy-Syahidiyah, Cisayong, } \\
19 \text { September } 2008\end{array}$ \\
\hline 10. & B-2 & PIC_0530-0535.AVI & Kyai Al-Faryzant & Kyai & $\begin{array}{l}\text { Asy-Syahidiyah, Cisayong, } \\
18 \text { Oktober } 2008\end{array}$ \\
\hline 11. & B-3 & PIC_0473.AVI & Uyun Wahyudin & $\begin{array}{l}\text { Santri Senior / } \\
\text { Ustaz }\end{array}$ & $\begin{array}{l}\text { Asy-Syahidiyah, Cisayong, } \\
18 \text { Oktober } 2008\end{array}$ \\
\hline 12. & B-4 & PIC_0472.AVI & Kamal & Santri & $\begin{array}{l}\text { Asy-Syahidiyah, Cisayong, } \\
18 \text { Oktober } 2008\end{array}$ \\
\hline 13. & B-5 & PIC_0474.AVI & Eka & Santri & $\begin{array}{l}\text { Asy-Syahidiyah, Cisayong, } \\
18 \text { Oktober } 2008\end{array}$ \\
\hline 14. & C-1 & Written & $\begin{array}{l}\text { KH. Asep Hidayat, } \\
\text { LC. }\end{array}$ & Kyai & $\begin{array}{l}\text { Al-Furqon, Singaparna, } 19 \\
\text { September } 2008\end{array}$ \\
\hline 15. & C-2 & PIC_0243-0246.AVI & Ustaz lqbal & Headmaster, MTs Al-Furqon & $\begin{array}{l}\text { Al-Furqon, Singaparna, } 15 \\
\text { Oktober } 2008\end{array}$ \\
\hline 16. & C-3 & PIC_0358-0364.AVI & Pak Deddy & $\begin{array}{l}\text { Head of Administration Pesantren } \\
\text { Al-Furqon }\end{array}$ & $\begin{array}{l}\text { Al-Furqon, Singaparna, } 17 \\
\text { Oktober } 2008\end{array}$ \\
\hline 17. & D-1 & PIC_0327-0334.AVI & Ustaz Yuyu Wahyu & $\begin{array}{l}\text { Headmaster, MTs Persis } \\
\text { Rajapolah }\end{array}$ & Rajapolah, 16 Oktober 2008 \\
\hline 18. & D-2 & PIC_0573-0574.AVI & $\begin{array}{l}\text { Ustaz Taimullah } \\
\text { As-Sabieq, S.Th.I. }\end{array}$ & $\begin{array}{l}\text { Vice Headmaster, SMA Plus } \\
\text { Muallimin Persis }\end{array}$ & Rajapolah, 18 Oktober 2008 \\
\hline 19. & D-3 & PIC_0578-0582.AVI & $\begin{array}{l}\text { Ustaz Abdul Aziz } \\
\text { Al-Fadhol }\end{array}$ & $\begin{array}{l}\text { Headmaster, SMA Plus Muallimin } \\
\text { Persis }\end{array}$ & Rajapolah, 18 Oktober 2008 \\
\hline 20. & D-4 & Written & $\begin{array}{l}\text { Dra. Yayah Siti } \\
\text { Aisyah }\end{array}$ & Headmaster, TK Persis Rajapolah & Rajapolah, 16 Oktober 2008 \\
\hline 21. & D-5 & Written & Dedi & $\begin{array}{l}\text { Alumni Pesantren Persis } \\
\text { Rajapolah }\end{array}$ & Rajapolah, 16 Oktober 2008 \\
\hline 22. & D-6 & Written & H. Dandi & $\begin{array}{l}\text { A son of Muwakif Pesantren } \\
\text { Persis Rajapolah }\end{array}$ & Rajapolah, 16 Oktober 2008 \\
\hline 23. & $\mathrm{E}-1$ & PIC_0377.AVI & $\begin{array}{l}\text { K.H. Baban Ahmad } \\
\text { Jihad }\end{array}$ & $\begin{array}{l}\text { Secretary of Pesantren } \\
\text { Suryalaya }\end{array}$ & $\begin{array}{l}\text { Suryalaya, Pagerageung, } \\
17 \text { Oktober } 2008\end{array}$ \\
\hline 24. & $\mathrm{E}-2$ & PIC_1598-1608-.AVI & $\begin{array}{l}\text { K.H. Zaenal Abidin } \\
\text { Anwar }\end{array}$ & & $\begin{array}{l}\text { Suryalaya, Pagerageung, } \\
30 \text { April } 2009\end{array}$ \\
\hline 25. & E-3 & PIC_1613-1608-.AVI & & Shop owner of photocopy & $\begin{array}{l}\text { Suryalaya, Pagerageung, } \\
30 \text { April } 2009\end{array}$ \\
\hline 26. & E-4 & PIC_1635-1636-.AVI & & Taylor of Pesantren Suryalaya & $\begin{array}{l}\text { Suryalaya, Pagerageung, } \\
30 \text { April } 2009\end{array}$ \\
\hline 27. & E-5 & PIC_1637-1644-.AVI & Pak Nana Heryana & $\begin{array}{l}\text { Secretary of Cooperation Khidmat } \\
\text { Pesantren Suryalaya }\end{array}$ & $\begin{array}{l}\text { Suryalaya, Pagerageung, } \\
30 \text { April } 2009\end{array}$ \\
\hline
\end{tabular}




\begin{tabular}{|c|c|c|c|c|c|}
\hline 28. & $\mathrm{E}-6$ & PIC_1647-1660.AVI & Hj. Otin & Director of Ibu Bella & $\begin{array}{l}\text { Suryalaya, Pagerageung, } \\
30 \text { April } 2009\end{array}$ \\
\hline 29. & E-7 & PIC_1665.AVI & Pak Jujun & Pesantren worker and shop owner & $\begin{array}{l}\text { Suryalaya, Pagerageung, } \\
30 \text { April } 2009\end{array}$ \\
\hline 30. & $\mathrm{~F}-1$ & Written & $\begin{array}{l}\text { K.H. Asep Bakhtiar } \\
\text { Rifa'i }\end{array}$ & Kyai & $\begin{array}{l}\text { Ar-Riyadh, Leuwisari, } 19 \\
\text { September } 2008\end{array}$ \\
\hline 31. & $\mathrm{~F}-2$ & PIC_0299-0301.AVI & $\begin{array}{l}\text { Ajengan Uen } \\
\text { Juwaeni }\end{array}$ & Ustaz of Pesantren Ar-Riyadh & $\begin{array}{l}\text { Ar-Riyadh, Leuwisari, } 15 \\
\text { Oktober } 2008\end{array}$ \\
\hline 32. & $\mathrm{~F}-3$ & $\begin{array}{l}\text { PIC_0251 and } \\
\text { 0253.AVI }\end{array}$ & Supriatman & Santri and teacher & $\begin{array}{l}\text { Ar-Riyadh, Leuwisari, } 15 \\
\text { Oktober } 2008\end{array}$ \\
\hline 33. & $\mathrm{~F}-4$ & $\begin{array}{l}\text { PIC_0371.AVI and } \\
\text { 0375.AVI }\end{array}$ & Dedi Supriadi & Santri and student of university & $\begin{array}{l}\text { Ar-Riyadh, Leuwisari, } 15 \\
\text { and } 17 \text { Oktober } 2008\end{array}$ \\
\hline 34. & $\mathrm{~F}-5$ & PIC_0371.AVI & Irfan & Santri and vocational student & $\begin{array}{l}\text { Ar-Riyadh, Leuwisari, } 17 \\
\text { Oktober } 2008\end{array}$ \\
\hline 35. & $\mathrm{~F}-6$ & PIC_0371.AVI & Heri Hermawan & Santri & $\begin{array}{l}\text { Ar-Riyadh, Leuwisari, } 17 \\
\text { Oktober } 2008\end{array}$ \\
\hline 36. & $\mathrm{~F}-7$ & PIC_0376.AVI & Farid & A son of Kyai & $\begin{array}{l}\text { Ar-Riyadh, Leuwisari, } 15 \\
\text { and } 17 \text { Oktober } 2008\end{array}$ \\
\hline 37. & G-1 & PIC_0575-0577.AVI & Pak Caca Slamet & $\begin{array}{l}\text { Supervisor of High Education of } \\
\text { North Tasikmalaya }\end{array}$ & $\begin{array}{l}\text { Rajapolah, Tasikmalaya, } 18 \\
\text { Oktober } 2008\end{array}$ \\
\hline 38. & G-2 & PIC_1101-1102.AVI & Pak Agus Sutisna & $\begin{array}{l}\text { Head of Sub-section of Religion } \\
\text { and Welfare, Local Government of } \\
\text { Kabupaten Tasikmalaya }\end{array}$ & $\begin{array}{l}\text { Kantor Pem. Kab. } \\
\text { Tasikmalaya, } 23 \text { Desember } \\
2008\end{array}$ \\
\hline 39. & G-3 & PIC_1102-1106.AVI & $\begin{array}{l}\text { Pak Ucu } \\
\text { Hermawan }\end{array}$ & $\begin{array}{l}\text { Head of Section of Junior High } \\
\text { School, Office of Education, } \\
\text { Kabupaten Tasikmalaya }\end{array}$ & $\begin{array}{l}\text { Kantor Dinas Pendidikan } \\
\text { Nasional, Tasikmalaya, } 23 \\
\text { Desember } 2008 \\
\end{array}$ \\
\hline 40. & G-4 & PIC_1107-1111.AVI & Pak Agus Abdullah & $\begin{array}{l}\text { Section Staff of Departement of } \\
\text { Religious Affairs, Kab. } \\
\text { Tasikmalaya }\end{array}$ & $\begin{array}{l}\text { Kantor Depag Kab. } \\
\text { Tasikmalaya, } 23 \text { Desember } \\
2008\end{array}$ \\
\hline 41. & G-5 & PIC_1115-1118.AVI & Pak Hedi Nugraha & $\begin{array}{l}\text { Head of Village, Kalimanggis, } \\
\text { Kecamatan Manonjaya, } \\
\text { Kabupaten Tasikmalaya }\end{array}$ & $\begin{array}{l}\text { Manonjaya, Tasikmalaya, } \\
23 \text { Desember } 2008\end{array}$ \\
\hline 42. & $\mathrm{H}-1$ & PIC_1112-1114.AVI & $\begin{array}{l}\text { KH. Ruhiyat } \\
\text { Effendy }\end{array}$ & $\begin{array}{l}\text { Alumni, Kyai of Pesantren } \\
\text { Miftahul Huda III }\end{array}$ & $\begin{array}{l}\text { Cibeureum, Kota } \\
\text { Tasikmalaya, } 23 \text { Desember } \\
2008\end{array}$ \\
\hline 43. & $\mathrm{H}-2$ & PIC_1120.AVI & $\begin{array}{l}\text { KH. Cecep Ridwan, } \\
\text { S.Ag. }\end{array}$ & $\begin{array}{l}\text { Alumni, Kyai of Pesantren Bahrul } \\
\text { Ulum; Vice President of DPRD } \\
\text { Kota Tasikmalaya }\end{array}$ & $\begin{array}{l}\text { Cibeureum, Kota } \\
\text { Tasikmalaya, } 23 \text { Desember } \\
2008 \\
\end{array}$ \\
\hline 44. & $\mathrm{H}-3$ & PIC_0523-0524.AVI & Pak Oto & Alumni, farmer & $\begin{array}{l}\text { Asy-Syahidiyah, Cisayong, } \\
18 \text { Oktober } 2008\end{array}$ \\
\hline 45. & |-1 & $\begin{array}{l}\text { PIC_1590- } \\
\text { 1597.AVI }\end{array}$ & Pak Surwan, S.Pd. & Santri's parent, teacher & Sumedang, 29 April 2009. \\
\hline 46. & |-2 & PIC_1665.AVI & Pak Junud Junaedi & $\begin{array}{l}\text { Santri's parent, pesantren's } \\
\text { worker }\end{array}$ & $\begin{array}{l}\text { Suryalaya, Pagerageung, } \\
30 \text { April } 2009\end{array}$ \\
\hline 47. & $1-3$ & $\begin{array}{l}\text { PIC_1666- } \\
\text { 1675.AVI }\end{array}$ & Drs. H. Muzakir & Santri's parent, teacher & $\begin{array}{l}\text { Kalangsari, Kota } \\
\text { Tasikmalaya, } 30 \text { April } 2009\end{array}$ \\
\hline
\end{tabular}

